\title{
A breve história da
} arte' e a arte indigena: a gếnese de uma noçäo e sua problemática hoje

\section{Fernanda Pitta}

\section{Como citar:}

PITTA, F. M. A 'breve história da arte' e a arte indígena: a gênese de uma noção e sua problemática hoje. MODOS: Revista de História da Arte, Campinas, SP, v. 5, n. 3, p. 223-257, 2021. DOI: 10.20396/modos.v5i3.8666380. Disponível em: https://periodicos.sbu.unicamp.br/ojs/index.php/mod/article/view/8666380

Imagem: Denilson Baniwa, Perfomance Pajé-Onça Hackeando a 33ª Bienal de Artes de São Paulo, HD vídeo, 16:9, cor, som, 15min , 17 nov. 2018.

Cortesia do artista. Crédito Fotográfico: José Moreau. 


\title{
A 'breve história da arte' e a arte indígena: a gênese de uma noção e sua problemática hoje
}

\author{
The 'short history of art' and Indigenous art: the genesis \\ of a notion and its problematics today
}

Fernanda Pitta*

RESUMO

O artigo examina a gênese da noção de arte indígena a partir do ensaio "l'Art" de

Eduardo Prado, publicado em francês no livro Le Brésil, em 1889. Historicizando a noção e refletindo sobre as implicações que teve essa invenção para a construção de uma ideia de arte brasileira, o artigo conclui com uma discussão a respeito das demandas contemporâneas formuladas por agentes e artistas indígenas que convidam a uma mudança de perspectiva: ao invés de assentar a origem de uma noção de arte brasileira na apropriação das manifestações artísticas indígenas, indigenizar o campo da história da arte no Brasil, respeitando as demandas de vários agentes indígenas que exigem que as instituições reconheçam suas cosmovisões, experiências e proposições sobre arte e criação.

PALAVRAS-CHAVE

Arte indígena. Historiografia da Arte. Arte no Brasil.

\section{ABSTRACT}

The article examines the genesis of the notion of indigenous art based on Eduardo Prado's essay "l'Art", published in French in the book Le Brésil, in 1889. Historicizing the notion and reflecting on the implications that this invention had for the construction of an idea of Brazilian art, the article concludes with a discussion about the contemporary demands formulated by indigenous agents and artists that invite to a change of perspective: instead of basing the origin of a notion of Brazilian art on the appropriation of indigenous artistic manifestations, to indigenize the field of art history in Brazil, respecting the demands of several indigenous agents who claim that institutions recognize their cosmovisions, experiences and propositions about art and creation.

KEY WORDS

Indigenous art. Historiography of Art. Art in Brazil. 
para pimi e os seus

Quando se fala em arte indígena, de que arte se está falando? No Brasil, quem foram aqueles que "inventaram" essa noção e a partir de que referências e experiências? E mais importante, na história das apropriações culturais das práticas, visões de mundo e concepções dos diversos povos indígenas vivendo no território brasileiro, em que lugar no campo da história da arte se situa a invenção que designa o que esses grupos criam e vivenciam como arte?

O presente artigo se propõe a examinar a gênese dessa noção, refletindo sobre as implicações que teve essa invenção para a construção da ideia de arte brasileira. Conclui com uma discussão a respeito das demandas contemporâneas formuladas por agentes e artistas indígenas que convidam a uma mudança de perspectiva: ao invés de assentar a origem de uma noção de arte brasileira na apropriação das manifestações artísticas indígenas, indigenizar o campo da história da arte no Brasil, respeitando as demandas de vários agentes indígenas que exigem que as instituições reconheçam suas cosmovisões, experiências e proposições sobre arte e criação. Tal conectividade, complexa e tensa, pode ser o caminho para a reelaboração de uma história da arte que negocie diferenças culturais, evite subsumir concepções e experiências artísticas distintas no bojo de um "nacional" aplainador, refute hierarquizações, anacronismos e coloque em causa uma verdadeira e mais que urgente pluralidade, capaz de expandir as noções de arte e seus significados para a experiência humana.

No início da interpretação que desenvolverei nesse artigo acerca da gênese da noção de "arte indígena" está a Exposição Universal de Paris, em 1889. Nela, Brasil e México apresentaram importantes coleções etnográficas e arqueológicas que vinham sendo organizadas nos respectivos países, por sua nascente comunidade de cientistas, arqueólogos e etnógrafos. 
A exposição de 1889 em Paris celebrava a queda da Bastilha, o que provocou o boicote de monarquias como a Inglaterra, Alemanha, o Império Austro-húngaro, Espanha, Itália, Bélgica, Países-baixos, Portugal e Rússia (Tenorio-Trillo, 1996). O Brasil decidiu participar, em uma tentativa que talvez fosse um último esforço em promover a imagem do Império frente à força das novas nações republicanas americanas. O México, por sua vez, no auge do porfiriato, afirmava-se como uma república ansiosa por utilizar seu passado pré-colombiano, visto como grandioso, como força unificadora do país, após décadas de instabilidade política - entre as iniciativas do governo de Diaz está a criação da secretaria de inspeção e conservação de monumentos arqueológicos, em 1885, chefiado por Leopoldo Bartres (Valiant, 2018).

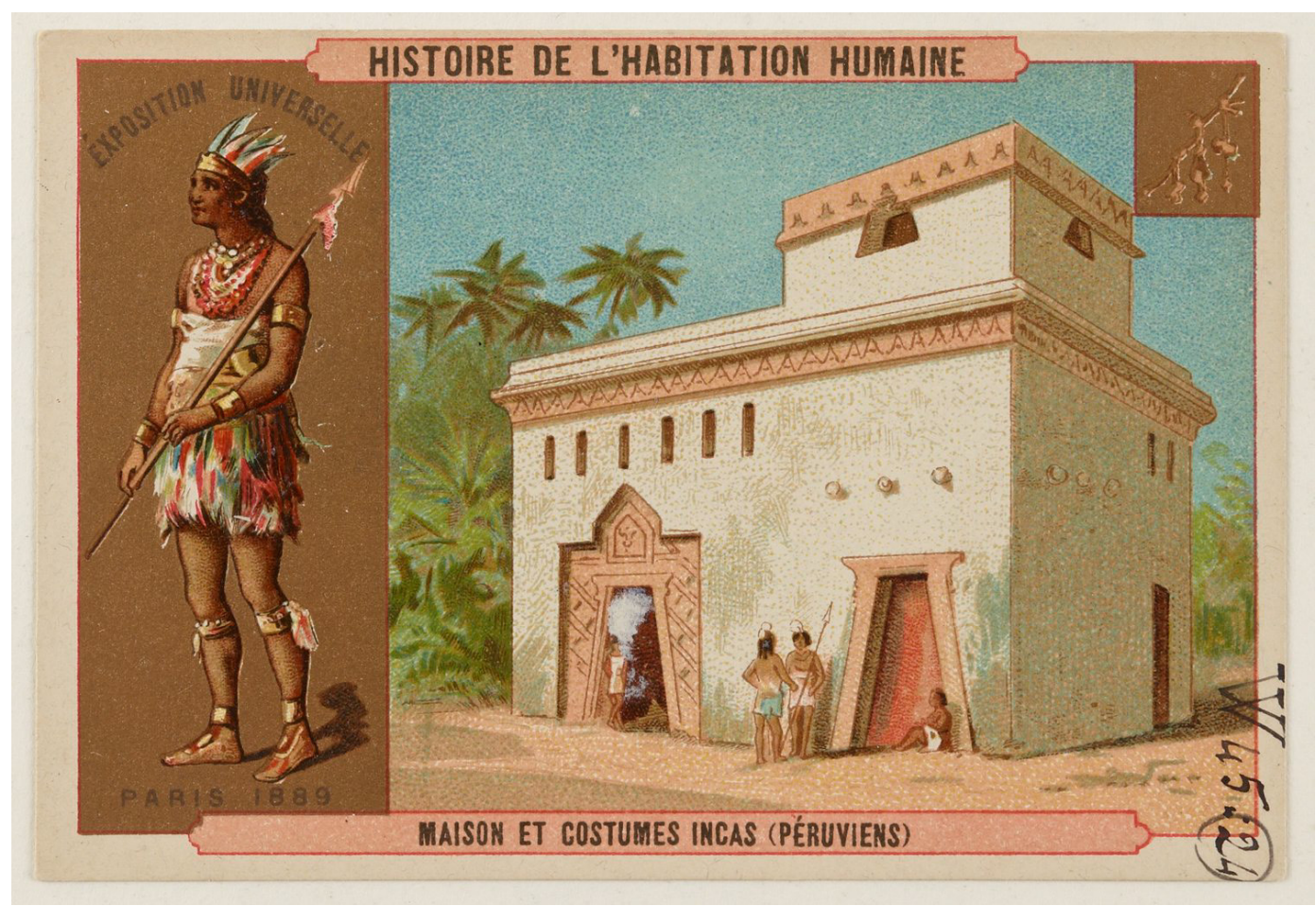

FIG. 1. Autoria não-identificada, «Maison et Costumes Incas (Péruviens)», in: Exposition universelle, Paris, 1889, 25 vignettes scolaires en couleur Représentant l'évolution de l'habitation/ humaine, don du prince Roland Bonaparte, 1889 , técnica e medidas não identificadas. Biblioteca Nacional da França, Gallica Disponível em: https://gallica.bnf.fr/ark:/12148/btv1b8470084p . 
O pavilhão do Brasil, de arquitetura hispânica, desenhado por Louis Dauvergne, fazia alusão às já tradicionais alegorias do período imperial, que tomavam os indígenas masculinos e femininos, realizadas pelo escultor francês Gilbert, para simbolizar a natureza brasileira, através dos seis maiores rios de seu território. O Império participava da exposição na tentativa de recuperar sua imagem internacional, a despeito da crise política que assolava o país.

O México por sua vez, em seu próprio pavilhão, desenhado por um arquiteto mexicano, Antonio Anza, com o auxílio de Luís Salazar, fazia representar não uma arquitetura europeia, mas sim aquela que tinha como referência os monumentos pré-colombianos, fato que denota o investimento em favor de um reconhecimento internacional da originalidade e grandiosidade artísticas do México pré-colonial. Além do pavilhão, o México também foi representado pela Casa Asteca, parte da exposição sobre a evolução da habitação humana, situadas logo abaixo da Torre Eiffel.

Todas as cerca de 32 casas (Bouvier, 2005) foram desenhadas por Charles Garnier, arquiteto da Opéra de Paris. A casa Asteca, cuja organização o governo mexicano relutou em participar, acabou acolhendo um grupo de indígenas enviados do México, sendo a sua consecução administrada privadamente por uma companhia americana (Tenorio-Trillo, 1996). O Brasil, por sua vez, não foi selecionado para ser representado na mostra retrospectiva da habitação, mas dela participou instalando na Casa Inca [fig.1], dedicada ao Peru, uma exposição de objetos arqueológicos e etnográficos brasileiros, organizada por Ladislau Netto, diretor do Museu Nacional do Rio de Janeiro. Em uma das salas dessa casa, conforme um dos guias da exposição, o Brasil expôs, em uma

reconstituição conscienciosa e erudita, os documentos mais raros e os mais sérios (...) um pequeno museu de antiguidades americanas (...) é curioso, esse pequeno museu, lá existem trajes completos de Botocudos e de Chivaros que não impressionam muito, pois eles são constituídos somente de clavas 
e brincos; existem vasos pré-históricos repletos de hieróglifos misteriosos e quase artísticos; também vemos, em um bocal, uma cabeça de homem horrível, desossada e cozida no forno, que não tem nada de pré-histórica, pois essa atrocidade não data de mais de dois ?; lá se pode também estudar todos os vestígios de uma religião primitiva, sobre a qual nós falaremos discretamente; aqueles entre os nossos leitores que visitaram o museu secreto de Nápoles e as antiguidades pompeanas compreenderão a razão de nossa reserva (L'Exposition de Paris, 1889: 219). ${ }^{1}$

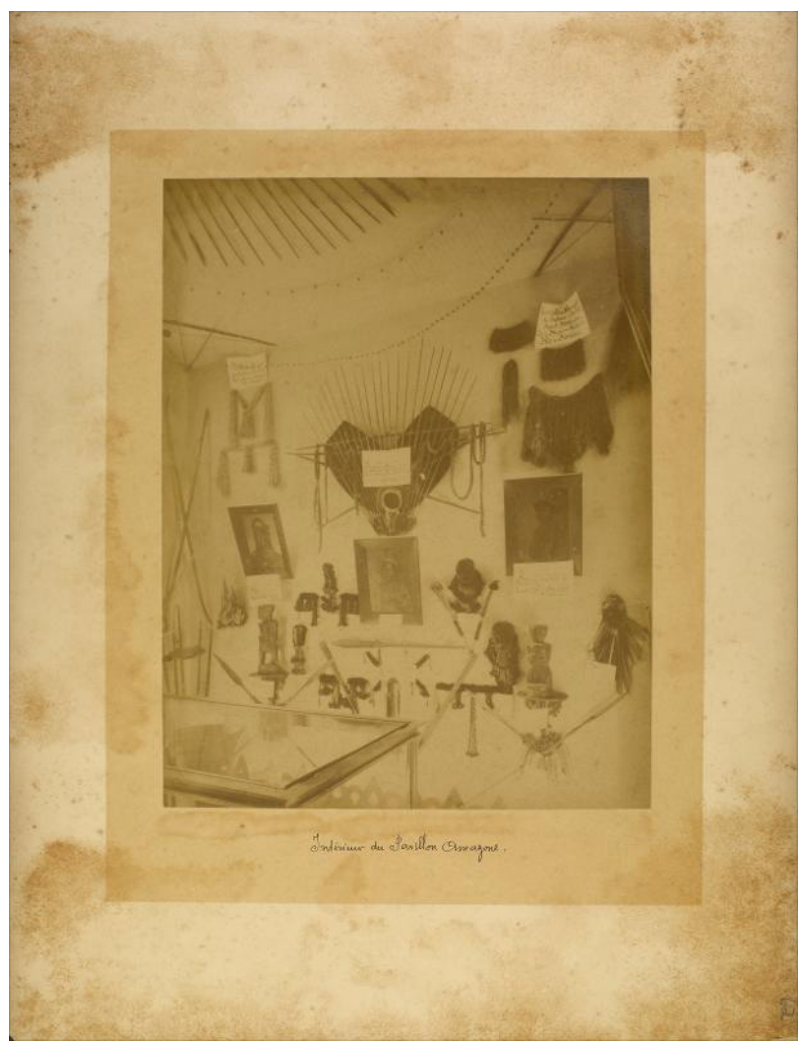

FIG. 2. Autoria não-identificada, Exposição Universal de Paris: exposição brasileira. Interior do Pavilhão Amazonas, 1889, Impressão albumina sobre papel, $21 \times 17 \mathrm{~cm}$ em álbum de $39 \times 28 \mathrm{~cm}$. Acervo do Arquivo Nacional [Brasiliana Fotográfica] Disponível em: https://brasilianafotografica.bn.gov.br/brasiliana/handle/20.500.12156.1/5696.

Na ocasião, o Brasil também mostrou sua produção de Belas Artes, com artistas selecionados pela Academia Imperial, expondo no pavilhão 
brasileiro, caso de artistas como Bérard, Abigail de Andrade, entre outros, mas também na seção geral de Belas Artes da exposição, em que expuseram Henrique Bernardelli e Almeida Júnior, entre outros. O Brasil também publicou um guia próprio, além de duas outras obras de maior vulto, Le Brésil, por Levasseur, e Le Brésil en 1889. Esta última, trazia textos do Barão do Rio Branco, Sant’anna Nery, Eduardo Prado, André Rebouças, Ladislau Netto, Capistrano de Abreu e Orville Derby, entre outros. O livro, organizado por Rio Branco, foi composto de vinte e cinco capítulos que percorriam temas como história, geografia, reflexões sobre o território, a questão do trabalho servil e livre, agricultura, finanças, transporte, comércio, comunicações, imprensa, contemplando também temas culturais: arte, instrução pública, literatura, ciência, além de expor o posicionamento brasileiro com relação às leis de propriedade industrial e intelectual, cuidados com a infância, organização judiciária, sem esquecer do tema da guerra, tratado no capítulo sobre os arsenais da Marinha (Nery, 1889).

O capítulo "L’Art”, de Le Brésil en 1889, foi redigido pelo intelectual paulista Eduardo Prado, que substituíra o crítico Félix Ferreira, primeiro encarregado de sua redação. Não obstante a troca de última hora, Prado se envolvera desde cedo com os trabalhos preparativos do projeto, e pôde com seu texto, inaugurar um capítulo original da recém-constituída história da arte brasileira, ao colocar no começo de sua narrativa sobre a arte nacional a produção das populações indígenas, além de tomá-las como esteio e modelo para o desenvolvimento daquilo que considerava ser urgente - as artes industriais nacionais.

Através do texto de Prado, é possível perceber o posicionamento da comissão da exposição com relação ao que se produzia em termos artísticos no Brasil, bem como refletir a respeito do lugar ocupado pelas belas-artes brasileiras no pavilhão do país. As belas artes brasileiras, aparentemente, não foram bem recebidas pelos resenhistas da exposição, se pudermos confiar nos comentários de um François Ervy, na Revue editada por Dumas 
(1889). O crítico apenas notava "alguns quadros ruins e esculturas escolares", preferindo ressaltar as riquezas naturais do país, como comentou Heloisa Barbuy (1996: 225). Mas elas eram apenas uma parcela do que se exibia como criação artística brasileira, dividindo espaço com as artes plumárias, a cerâmica, as artes decorativas, e de certa maneira contrastadas, às manifestações da cultura popular.

Barbuy nota que a Galeria de Belas Artes do pavilhão brasileiro era um espaço acanhado, como se depreende também da fotografia preservada no álbum Exposição Universal de Paris: exposição brasileira, reproduzida no artigo da autora. Nele foram expostos estudos para as pinturas de batalha de Victor Meirelles e Pedro Américo, telas de paisagem de Belmiro de Almeida, Abgail de Andrade, Julio Balla, Leon Righini, Telles Júnior, Fachinetti, naturezas-mortas de Estevão da Silva, o estudo para a alegoria da Abolição da Escravatura, de Daniel Bérard. Os trabalhos de Henrique Bernardelli e F.F. de Sá, entretanto, parecem ter sido alocados no pavilhão destinado às Belas Artes, pois concorriam à premiação do júri. É possível encontrar referência à uma obra de Bernardelli, listada entre as pinturas italianas, com o título Le bandolero. O quadro Os Bandeirantes aparece também intitulado como Les Explorateurs, (El-Dorado, segundo Eduardo Prado e Rio Branco), arrolado na Seção Internacional do Palácio de Belas Artes no Champs de Mars. A tela de Almeida Júnior, Caipiras Negaceando, de 1888, também exposta na seção geral, com o título Paysans à l'affut, não está registrada, entretanto, na mesma listagem que as obras de Bernardelli e Franco de Sá.

Tanto Rio Branco quanto Prado, nos seus textos sobre as artes no Brasil das edições de Lévasseur e de Nery, demonstram um certo descontentamento com o que se havia produzido até então no campo das belas artes no Brasil. Rio Branco criticava, nas entrelinhas, as grandes dimensões das pinturas de história, considerando-as difíceis de alocar no espaço da exposição. Considerava também insuficientes os esforços dos artistas em representar a paisagem brasileira, embora, como notou Barbuy, as pinturas de paisagem 
fossem apresentadas em grande número no pavilhão brasileiro, juntamente com um número significativo de naturezas-mortas, todas de Estevão Silva (Barbuy, 1996: 226). O texto do Barão foi acompanhado, ainda assim, de reproduções das grandes "máquinas" de Victor Meirelles e Pedro Américo, contrastando com a opinião registrada em suas linhas.

O capítulo redigido por Eduardo Prado para o livro editado no contexto da exposição é o foco das reflexões seguintes. Primeiramente o texto do intelectual paulista interessa por revelar o posicionamento da comissão da exposição com relação ao que se produzia em termos artísticos no Brasil: o que pretendia apresentar para o público parisiense e internacional, como o resultado da produção artística oficial brasileira. Mas ele também é uma excelente ocasião para compreender como esse grupo de intelectuais e políticos refletia a respeito do lugar ocupado pelas belas-artes na constituição do país, além de expor uma noção inédita e peculiar acerca da arte nacional.

O primeiro aspecto a ser observado é o quanto as ideias do texto de Eduardo Prado são devedoras de publicações que haviam sido recémeditadas no Brasil, nomeadamente de Félix Ferreira, Belas Artes e apreciações, publicado em 1885, e de todo debate artístico que se intensificara a partir de fins da década de 1870, em especial em torno da noção de Escola Brasileira. Um segundo ponto que nos interessa ressaltar é a originalidade desse texto em dois aspectos: a reunião inédita que faz de fontes diversas sobre a produção artística no Brasil, especialmente a partir de relatos dos viajantes, mas, sobretudo, a estrutura narrativa desse relato que dá destaque inédito à arte indígena produzida entre as populações que viviam no território brasileiro. Esse último aspecto é em grande medida inaugural, tendo como precedentes textos como os de Charles Hartt, "Beginning of art, or evolution in ornament", de 1873, e o de Félix Ferreira redigido na ocasião da grande Exposição Antropológica de 1882, "As artes industriais indígenas", ambos publicados na revista do evento (Hartt, 1882; Ferreira, 1882). As formulações 
acerca da arte indígena desses autores seriam destinadas a uma longevidade que precisa ser assinalada e ainda compreendida.

O texto de Eduardo Prado é muito mais extenso do que aquele de Rio Branco. Nele, as artes "visuais" são apenas uma parte do patrimônio artístico brasileiro, denotando uma inédita e complexa compreensão das artes feitas no Brasil. $\mathrm{O}$ autor não se restringe à noção de belas artes, cujo sustentáculo havia sido a Academia Imperial de Belas Artes. Sob esse enfoque, o exame das belas artes feito pelo intelectual, assim como no texto de Rio Branco, denota descontentamento com o sistema artístico que se criara no Brasil, a partir da vinda da corte e da criação da Academia. Aos olhos de Prado, ele não apresenta a mesma coesão e consistência que aquele desenvolvido durante o período colonial.

Embora considere que possam ser encontradas produções de qualidade e valor artístico, Prado não vê, por exemplo, artistas que na sua opinião tenham conseguido vencer as dificuldades apresentadas pela paisagem brasileira:

(...) para a paisagem europeia, escolas existem, os modelos são conhecidos. Diante de uma natureza cuja reprodução não se encontra nas telas dos mestres, a individualidade do artista deve ser revelar no modo que apanha essa natureza, cujas violências de tom e de formas exóticas riscam impressionar desagradavelmente o olho exercitado de um conhecedor europeu (Prado, 1889: 534). ${ }^{2}$

Por essas razões, Prado considera que "depois de Post e Van Eckhout, a paisagem do Brasil ainda não encontrou o seu grande pintor"3 (Ibidem), ainda que fossem de notar as produções dos viajantes, e, timidamente, aquelas de paisagistas como Facchinetti, Wygandt, Grimm, Caron e Vasquez. Prado apenas cita o nome de alguns jovens pintores, como Abigail de Andrade, Castagneto, Parreiras, Belmiro de Almeida, Villares, Pereira da Silva, Pinto Peres, Medeiros, Zeferino da Costa, Estevão da Silva, Leôncio Vieira, Bérard, Weingartner, Balla, Franco de Sá, Firmino Monteiro. Destaca, entre eles, Henrique Bernardelli, comentando que o seu L'Eldorado, apresentado na 
exposição, é "um belo quadro"4 (Ibidem). Almeida Júnior é considerado um "aluno notável de Cabanel"5 (Ibidem), seus trabalhos, segundo ele, revelariam "as grandes qualidades do artista" (Ibidem), embora o autor não os comente. Aurélio de Figueiredo e Amoêdo também são merecedores, em sua opinião, dos mesmos elogios. Na escultura, o destaque vai para Rodolfo Bernardelli, de que cita a obra [Cristo e] A mulher adúltera, Faceira e as estátuas de Alencar e José Bonifácio.

O espaço dado às Belas-Artes no texto de Prado é bastante exíguo se comparado ao destaque às outras manifestações artísticas. E os motivos para esse fato residem no seu descontentamento com essa produção, sobretudo numa inédita concepção de arte do autor, mais abrangente, que abarcava também os monumentos arquitetônicos, o paisagismo, as manifestações da arte ornamental indígena (em especial a plumária), arte utilitária (a cerâmica), arte decorativa, a cultura oral popular (canções, trovas), a música, erudita e popular, de matriz ibérica e indígena. É notável a valorização que faz da produção colonial, entendida na sua integridade de arquitetura, decoração, escultura e pintura.

$\mathrm{O}$ apanhado que faz de todas essas manifestações é sugestivo tanto pela erudição e interesse investigativo do círculo intelectual ao qual pertenceu Prado, mas também de uma noção renovada do que constituíam as manifestações artísticas, já compreendidas aqui como produtos culturais de formações históricas, étnicas e sociais específicas. No caso de Prado, é evidente que o intelectual faz um esforço de demonstrar que o Brasil tem uma cultura própria, criada ao longo dos anos de sua formação (e muito anterior à sua fundação enquanto nação), que expressam as qualidades e características de um povo singular.

O Brasil, para o autor, teria a "preocupação artística"7 (Prado, 1889: 557) e a capacidade criativa, o que lhe faltava era um sistema de promoção à produção artística que estimulasse esses dons e propensões. Não importava que o país não tivesse grandes artistas. Para Prado, o número de maus 
artistas no Brasil era grande, mas essas falsas vocações teriam "um grande valor porque demonstram que a preocupação artística se torna cada vez mais geral"8 (Prado, 1889: 557). O problema, a seu ver, era que a atividade havia se tornado veículo para celebridades fáceis, amparadas sobretudo por interesses de favor e proteção, em detrimento dos valores de formação e do desenvolvimento de uma expressão artística "genuinamente" brasileira. Nesse sentido, a prática do envio de artistas para completar sua formação no exterior era, para Prado, o coroamento de um sistema falho e pernicioso, custoso e estéril.

Para reverter esse quadro, seria necessário criar um sistema que se apoiasse não na notoriedade e na fama de alguns poucos selecionados, mas em duas bases: riqueza e instrução. Para cumprir o primeiro requisito, o Brasil dispunha de riquezas naturais, que precisavam ser melhor conhecidas e exploradas, mas faltava-lhe criar uma "verdadeira aristocracia", em termos econômicos e culturais, que pudesse apoiar o desenvolvimento das artes. Para alcançar o segundo, cabia investir na instrução básica, geral da nação, e na instrução técnica e profissional de "uma certa classe de indivíduos"9 (Prado, 1889: 559), dois aspectos em que o Brasil ainda era bastante devedor, conforme Prado. A Academia não havia dado grandes resultados e encontrava-se desorganizada, sendo uma instituição inócua. Faltava uma verdadeira promoção pública da arte por parte do Estado, que deveria ser sustentada através da construção de monumentos, edifícios exemplares, museus, em esforços articulados com a promoção da educação de base, da formação técnica e profissional. Só assim a arte se tornaria manifestação de uma "civilização nacional". Não era ainda necessário ter grandes artistas. Para o futuro da arte no Brasil seria "mais importante que uma grande parte da população" soubesse "um pouco de desenho do que ter três ou quatro Meissoniers ou Cabanéis" ${ }^{10}$ (Prado, 1889: 561).

As palavras de Prado encontram muitos pontos de contato com as avaliações de Félix Ferreira (2012) e Gonzaga Duque (1995) acerca da "arte 
nacional", desenvolvidas nas últimas décadas do século XIX. Para esses observadores, não surgira até então uma verdadeira arte brasileira, com características originais. Os esforços dos artistas, embora notáveis, eram considerados pequenos em relação às demandas de um verdadeiro tecido sociocultural que pudesse criar condições para uma expressão mais orgânica das potencialidades e dos talentos latentes na cultura do país. Antes de poder ter clareza em relação ao que consistiam esses atributos, era necessário promover uma completa reforma nas condições do sistema de promoção artística e cultural da nação. Diante do tamanho e da premência das necessidades apontadas por esses autores, a produção concreta dos artistas ficava relegada a segundo plano, sendo ela própria um testemunho das fragilidades do meio de onde surgiam.

O que gostaria de destacar, para além desses aspectos, é a originalidade do relato de Prado no que diz respeito ao tratamento dado à produção indígena. Nele aparece sintetizada uma opinião que vinha se gestando entre intelectuais e críticos das duas décadas precedentes, entre os quais os já citados Charles Frederick Hartt e Félix Ferreira, além de Orville Derby e Ladislau Netto: a de que a cultura material indígena deveria ser considerada como arte, constituindo elemento chave, e originário, de uma ideia de arte nacional original.

Em seu texto, Prado centra-se no exame das manifestações da arte plumária e da cestaria. Ainda que contraste com as Belas Artes àquela que considera ser a "arte rudimentar que se havia encontrado entre os indígenas do Brasil"11 (Prado, 1889:519), dedica boa parte de seu texto a desenvolver uma apreciação dessa produção, sublinhando as então recentes descobertas de produtos cerâmicos na Amazônia, considerados de particular ornamentação e de um "certo desenvolvimento saliente na beleza das formas" ${ }_{12}$ (Ibidem), revelando, de seu ponto de vista, "a existência, ou talvez a passagem sobre as margens do grande rio, de povos mais avançados [sic], pelo menos do ponto de vista industrial, que seus sucessores atuais nas mesmas regiões" ${ }^{13}$ (Ibidem). 


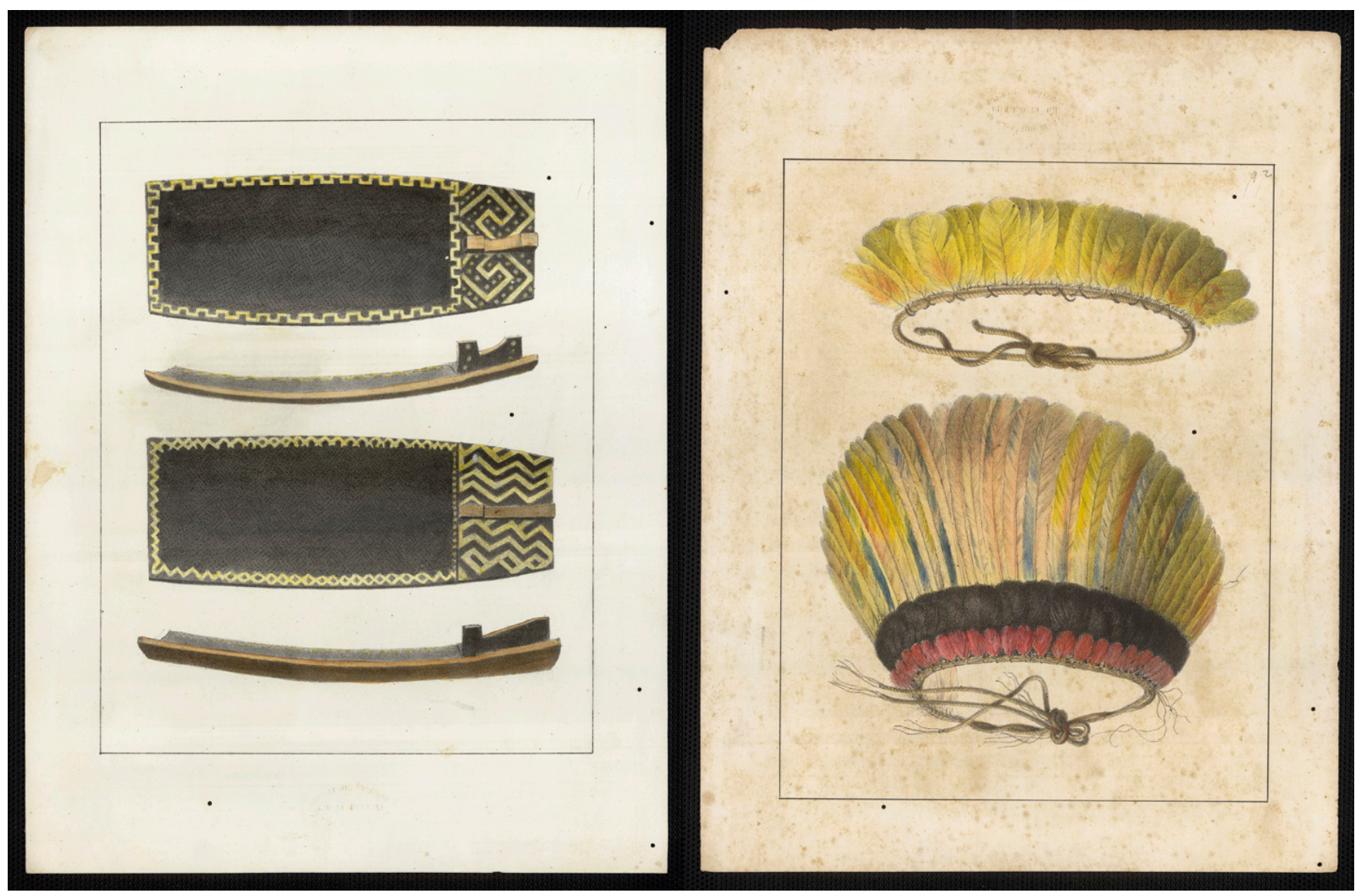

FIGS. 3-4. Comissão Científica de Exploração do Ceará. Secção Etnográfica, Artefatos indígenas: utensílios 05, 1862 e Artefatos indígenas: adornos 19, 1862, litografia sobre papel, sem medidas, Rio de Janeiro : Instituto Artístico Lithográphico dos Irmãos Fleiuss. Acervo da Fundação Biblioteca Nacional do Rio de Janeiro. Disponível em: http://objdigital.bn.br/acervo_digital/div_iconografia/icon309821/ icon309821_071.jpg e http://objdigital.bn.br/acervo_digital/div_iconografia/icon309821/icon309821_096. jpg6.

Prado considera a arte da ornamentação plumária aquela que mais se destacaria entre as produções com as quais haviam se deparado os primeiros invasores. A existência de uma designação própria "arte plumária", denotaria, segundo ele, o quanto essa arte era de destaque, chamando a atenção de cronistas espanhóis que assim a teriam denominado.

A variedade de ornamentos e a riqueza de plumagens encontradas entre os indígenas na América do Sul teriam causado admiração entre os primeiros viajantes como Jean de Léry (1961), que descreve as penas de 
Arara, Canindé, e as produções exuberantes dos tupinambás, como roupas, adornos de cabeça, braceletes entre outros ornatos, muitas vezes finamente trançados com palha de tucum, entre outras fibras, e protegidas de resinas vegetais. Prado ainda ressalta o fato dessas tradições se manterem entre muitos povos, capazes, segundo ele, de fazer as "mais belas oposições e gradações de cor, com o vermelho cor de fogo em chama, o amarelo de um rico tom de narciso e do azul mais bonito"14 (Prado, 1889: 520). Em nota, lembra dos espécimes reproduzidos nas ilustrações de Debret para o seu livro sobre o Brasil, assim como as litografias coloridas produzidas para ilustrar o livro nunca publicado sobre os trabalhos da Comissão Geográfica e Geológica do Império na expedição do Ceará [figs.3-4], conhecidas por terem sido mostradas na exposição de História do Brasil, realizada na Biblioteca Nacional em 1881.

Prado, a essa altura do texto, resume as artes indígenas aos ornamentos plumários, objetos de adorno, ornamentação de armas e instrumentos musicais, lamentando as frustradas tentativas de encontrar grandes monumentos construídos por indígenas no território brasileiro. Ainda assim, após perfazer um percurso cronológico pelas manifestações artísticas posteriores à conquista, da arquitetura, passando pela escultura, até chegar à pintura, comentando o paisagismo e os interiores, até chegar à arte da ornamentação (dando destaque aquelas que hoje chamaríamos de populares), o autor retorna às artes cerâmicas, iniciando por aquelas produzidas entre os povos indígenas.

Para tanto, recorre justamente aos escritos daquele que foi talvez realmente o primeiro estudioso a reclamar o valor artístico das produções materiais indígenas do território brasileiro, o geólogo, paleontólogo e naturalista canadense Charles Frederick Hartt. Em seu ensaio inaugural "Origem da arte ou evolução do ornamento", escrito após as suas viagens de investigação ao Brasil em 1867 e 1870-71, Hartt sustentou a necessidade de considerar os ornamentos presentes nos objetos indígenas como "arte" Muito antes da discussão inovadora de Alois Riegl sobre os aspectos estéticos 
da ornamentação, apresentada em Stilfragen (1893), a pesquisa de Hartt abriu o caminho que permitiu aos intelectuais brasileiros reivindicarem o caráter artístico da cultura material indígena, e considerá-la como possível fundamento de um estilo nacional.
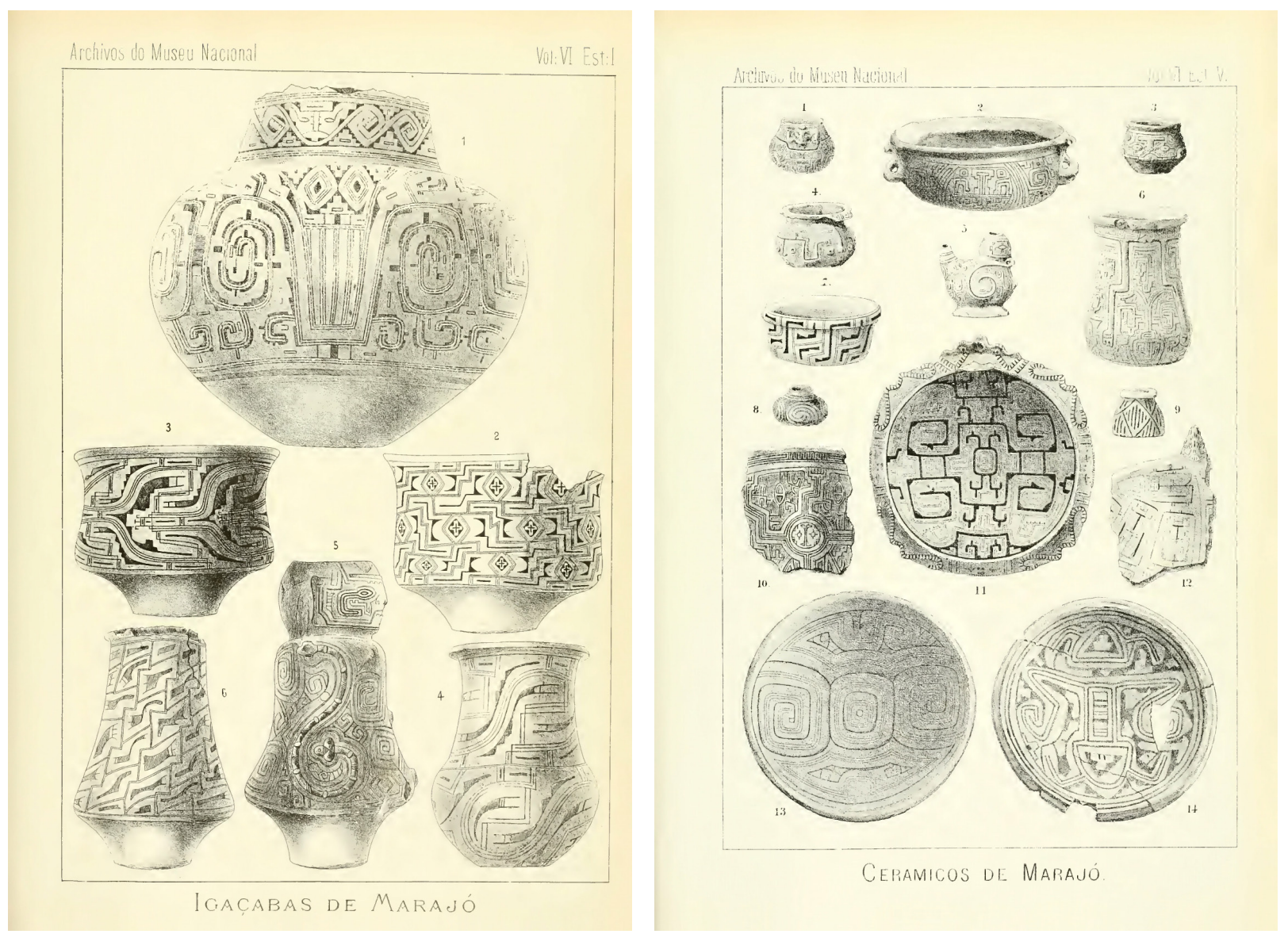

FIGS. 5-6. Autoria não identificada, Igaçabas de Marajó e Cerâmicos de Marajó, 1885, in Archivos do Museu Nacional. Rio de Janeiro: Typographia e Lith. Economica, 1885, vol.6 estampas I e V.

Prado comenta os achados de Hartt e analisa as diferenças entre as produções de cerâmica crua e cozida amazônica (esta última considerada por ele também mais "avançada" em termos tecnológicos e artísticos), descreve as características de algumas urnas funerárias e se concentra em descrever os achados arqueológicos de Hartt e sua equipe na ilha de 
Marajó, nos mounts do Pacoval, sustentando que eles haviam mudado as percepções acerca da indústria indígena, por ultrapassarem, segundo ele, a produção utilitária e expressarem imaginação e pensamento "artístico", em concordância com as noções de arte elaboradas por teóricos como Charles Blanc, a quem cita:

Do dia que a obra do ceramista, diz ele, foi concebida como um símbolo, do dia em que o vaso foi imaginado, não mais para um uso doméstico, mas para exprimir um pensamento ou um sentimento, para se tornar um presente de amizade, uma prova de amor, ou um puro objeto de luxo, a cerâmica se elevou à categoria das artes, e então submetida às três condições eternas do belo: a ordem, a proporção e a harmonia (Prado, 1889: 542)16

De acordo com Prado, os vasos e pratos encontrados em Marajó revelavam a arte dos artistas (os quais ele reconhece serem mulheres, pelas impressões dos dedos no interior de certos potes, feitos de rolos de terra dispostos em espiral), não só pela observância "instintiva" de regras artísticas, mas sobretudo pela preocupação com a figura humana "que é ao mesmo tempo a mais alta e primeira expressão da arte" ${ }^{17}$ (Ibidem).

Ainda segundo Prado, os vasos demonstram belas proporções e "revelam todos uma preocupação de beleza da parte do artista que não se contentou em obter a simples convenção, tanto quanto a forma quando a decoração gravada ou pintada"18 (Ibidem). Todos teriam:

a primeira condição dos produtos cerâmicos, quer dizer um senso bem definido, ou se quisermos, uma dimensão dominante. Para dar uma ideia de seu caráter e originalidade, é suficiente dizer que, a despeito da beleza desses vasos, não se pode a rigor os identificar em sua forma a nenhum vaso grego, pois eles apresentam combinações verdadeiramente novas da ovoide com as formas cilíndricas e clavoides com abaulamentos e contrações harmoniosas. Quanto à sua policromia, ela é caracterizada pelo amarelo, o cinza, o rosa e o vermelho alaranjado, e um pouco de preto nos detalhes, mas jamais como fundo. $O$ que parece mais curioso na ornamentação desses vasos, é que são? observados três ornamentações bastante distintas umas 
das outras: as gregas, sejam as retilíneas ou curvilíneas de enrolamento ondulados e contidos; os ornamentos de linhas fragmentadas, coligadas em espiral, em dois vasos cinzas ornados de preto não se encontra nenhum desses caracteres. Os objetos esculpidos devem ser anteriores aos potes pintados. Os estudos feitos até o momento não autorizam nenhum tipo de classificação. As descobertas do Marajós são recentes, e o problema da passagem pela Amazônia, de homens mais civilizados que os Indígenas atuais pertence às hipóteses dos etnógrafos, saindo de nosso plano; o que quisemos apenas foi assinalar essas descobertas de Marajó, que o Museu do Rio de Janeiro fez conhecer através do sábio recolhido de seus Arquivos já citados e cuja publicação é devida ao senhor Ladislau Netto (Prado, 1889: 542-543). ${ }^{19}$

Apesar das limitações de fontes e da visão marcadamente evolucionista das análises de Prado, é fato que seu escrito corrobora uma mudança expressiva relativa à apreciação das artes indígenas produzidas pelos povos originários no território brasileiro. Ele também constrói as condições de possibilidade para a operação discursiva que passaria a considerar essa produção a "origem" de uma arte nacional - característica das gerações intelectuais posteriores, com mais ênfase a partir do modernismo. No contexto histórico e intelectual do autor, é clara a ambivalência que marca a apreciação dos achados arqueológicos, antropológicos e etnográficos da pesquisa de então. Por um lado, o entusiasmo em encontrar produções que são consideradas índice de evolução - como as representações figurativas em vasos e outros artefatos, ou as refinadas técnicas de composição e colorido das artes plumárias - convive com a frustração diante da suposta ausência de monumentos, que permitiriam construir uma ideia de "antiguidade" americana à altura dos outros povos do continente. A descobertas dos mounts no Pacoval e outras partes do país havia ao menos sinalizado a existência de "construções" antigas, mas nada que se pudesse comparar aos monumentos incas, astecas ou maias. Tampouco se dava atenção às inscrições rupestres, 
nem mesmo aos geoglifos, dado que, na opinião da ciência de então, não constituíam "escritas" propriamente ditas, sendo desconsideradas como produção visual de interesse. Não obstante, é de se notar que a via aberta por Prado, Hartt, Ladislau Netto e Ferreira seria fundamental para que a arte indígena fosse incorporada à noção de arte brasileira.

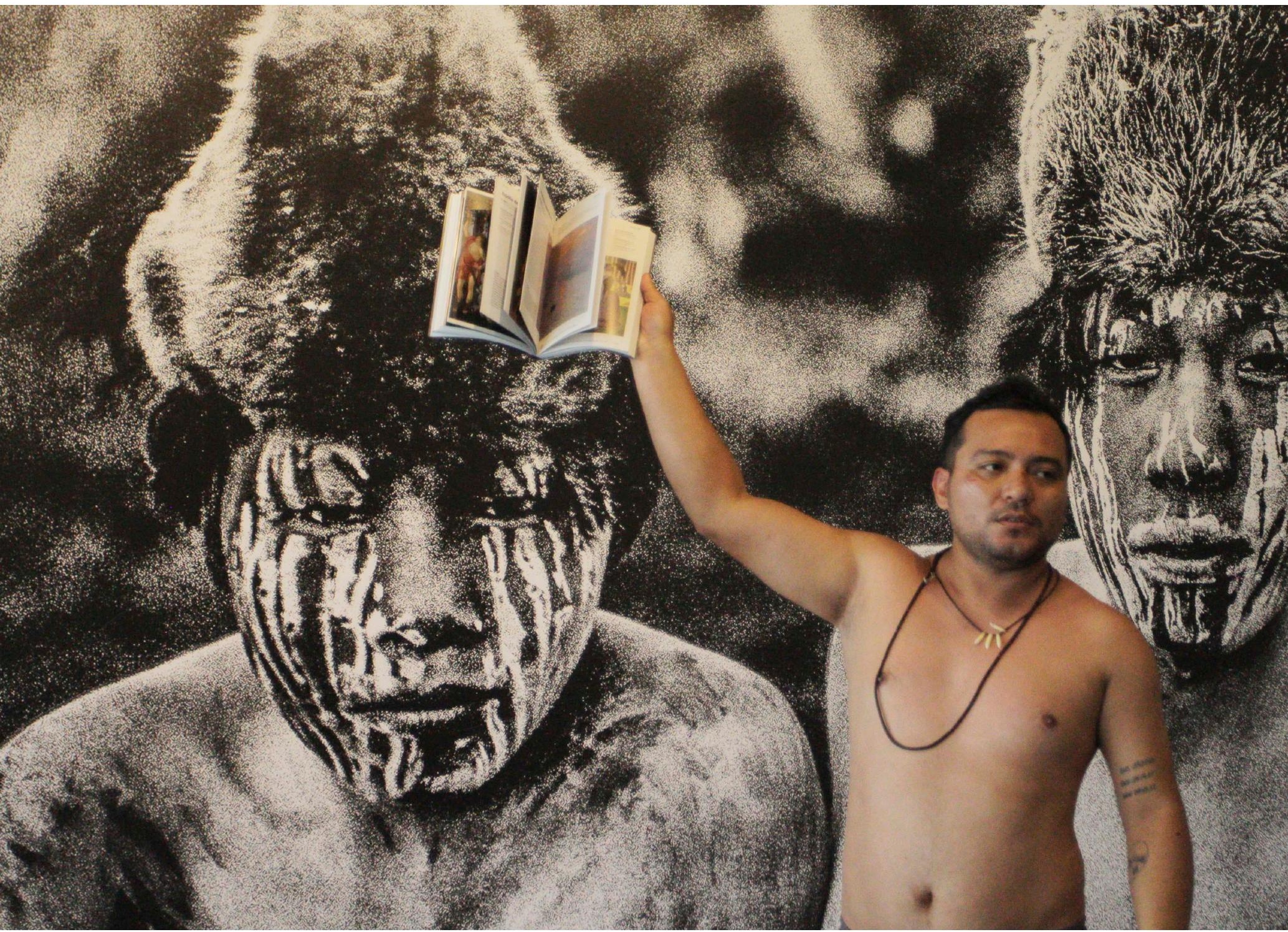

FIG. 7. Denilson Baniwa, Perfomance Pajé-Onça Hackeando a $33^{a}$ Bienal de Artes de São Paulo, HD vídeo, 16:9, cor, som, 15min , 17 nov. 2018. Cortesia do artista. Crédito Fotográfico: José Moreau. 
Nas narrativas posteriores, a presença da arte indígena em manuais, livros panorâmicos e coleções, tornar-se-ia recorrente, quase como um topos de uma ideia de arte nacional. Ainda que reiterada, é interessante notar que ela contrasta a quase absoluta ausência da mesma produção nos museus de arte brasileira: à parte a cultura indígena ser onipresente como repertório, referência, "influência" e tema, como já explicitou Denilson Baniwa em sua

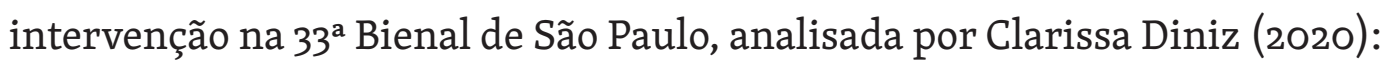

Eu vejo índios nas referências, vejo índios e suas culturas roubadas. Breve história da arte. Roubo. Roubo. Roubo. Isso é o índio? Aquilo é o índio? É assim que querem os índios? Presos no passado, sem direito ao futuro? Nos roubam a imagem, nos roubam o tempo e nos roubam a arte. Breve história da arte. Roubo, roubo, roubo, roubo, roubo, roubo, roubo. Arte branca. Roubo, roubo. Os índios não pertencem ao passado. Eles não têm que estar presos a imagens que brancos construíram para os índios. Estamos livres, livres, livres. Apesar do roubo, da violência e da história da arte. Chega de ter branco pegando arte indígena e transformando em simulacros! (Baniwa, 2018, apud Diniz, 2020: 79). ${ }^{20}$

Mesmo na produção acadêmica sobre a história da arte no Brasil, pouco existe sobre a produção artística indígena, estudada quase que exclusivamente por antropólogos e etnólogos. Nenhum programa de pós-graduação em história da arte tem hoje uma linha de pesquisa especificamente dedicada à história da arte indígena no Brasil ${ }^{21}$. No campo específico da história da arte, faltam estudos que inscrevam essa produção numa perspectiva mais ampla da arte brasileira, assim como aqueles que historicizem a arte indígena a partir de seus próprios termos, construindo suas próprias genealogias, critérios e questões, ainda que tenhamos hoje os importantes trabalhos realizados pela pesquisadora Ilana Goldstein, que ministra a disciplina de Arte Indígena da graduação em história da arte da Unifesp e que tem se dedicado especialmente a analisar as formas 
de institucionalização recentes da arte indígena contemporânea, de Amy Buono (2019), sobre arte plumária, e os de Daniela Kern, que desde os anos 2010 tem pesquisado a questão historiográfica ${ }^{22}$.

Por inúmeras razões históricas, que não serão exploradas aqui, a arte indígena, ainda que pertencente ideologicamente ao campo da história da arte brasileira, também não foi incorporada aos acervos dos museus de arte. Sendo considerada fonte de inspiração, originalidade e especificidade da arte produzida no Brasil, naturalizou-se sua invisibilidade dentro dos acervos das instituições artísticas, ainda que tenha havido esforços de constituição de coleções, como aquela reunida por José Teixeira Leite durante sua gestão no MNBA entre 1961 e $1964^{23}$, e exposta naquele período num esforço de ampliação da narrativa do museu, que também incluía a arte de matriz africana ${ }^{24}$. Em São Paulo, apenas no final da segunda década dos anos 2000, museus como a Pinacoteca, o MASP e o MAM passaram a preocupar-se com a ausência de obras de artistas indígenas, do passado e do presente, em suas coleções e programas expositivos ${ }^{25}$. E somente na $34^{\mathrm{a}}$ edição da Bienal um número consistente de artistas indígenas contemporâneos é escolhido para apresentarem seus trabalhos como artistas convidados, não apenas como participantes de trabalhos de outros artistas ou projetos especiais ${ }^{26}$, isto muitos anos após as primeiras exposições dedicadas à arte plumária, arqueologia, entre outras manifestações das artes dos povos ameríndios serem realizadas no âmbito deste evento.

De tão naturalizada na narrativa, a ausência concreta da arte indígena nas coleções de arte - do século XIX até agora - seja à vista dos especialistas, estudantes ou público, não implicou em nenhuma mudança expressiva nos modelos narrativos da arte brasileira, que ainda se valem dessa estrutura mítica de uma narrativa de origem situada na arte indígena e frequentemente recorrem a ela, seja para procurar fonte de originalidade, elementos pretensamente autóctones da cultura nacional, ou mesmo para esboçar posicionamentos críticos solidarizando-se com as questões como a 
demarcação de terra, a crise ambiental ou o racismo.

No contexto brasileiro, a narrativa da arte indígena foi certamente um constructo modernista, seu edifício, entretanto, foi sem sombra de dúvida erigido pela geração de Eduardo Prado. Se Mario Pedrosa foi aquele quem melhor elaborou a síntese dessa narrativa em um universalismo estratégico que pretendia defender uma noção de arte alargada e inclusiva, como a se depreende de seu projeto para o "Museu das Origens", ele foi herdeiro de uma tradição longeva. O projeto concebido para o MAM do Rio de Janeiro, destruído por um incêndio em 1978, consolidava um esquema que havia sido construído em um longo processo, resumindo e expandindo essa narrativa já então canônica da arte no Brasil: Museu de Arte Indígena, Museu do Inconsciente, Museu Afro-brasileiro e africano (Museu do Negro), Museu de Arte Virgem (Pedrosa, 1978) ${ }^{27}$.

A construção interpretativa da arte indígena brasileira como uma espécie de mito de origem da arte nacional já havia aparecido em diversas narrativas panorâmicas anteriores ao projeto de Pedrosa, e ainda se manteria como estrutura predominante em todas as subsequentes. Essa perspectiva de uma "originalidade" que poderia ser encontrada nos exemplos da arte e arqueologia indígenas foi elaborada pelas vanguardas modernistas dos anos 1900 e 1930, entre artistas como Theodoro Braga (1905-1914), Vicente do Rego Monteiro (1923), Manoel Pastana (1937), Carlos Hadler (c.1930) ${ }^{28} \mathrm{e}$ Manoel Santiago. Serviu de modelo, "pirateada" também por artistas como Correia Dias, Íris Pereira, Camila Álvares de Azevedo e Maria Marcelina Falcão ${ }^{29}$. Ela também tem um forte impacto, enquanto modelo narrativo, nos escritos sobre arte no Brasil em todo o século XX, de autores que vão de Angyone Costa, Francisco Acquarone, a Frederico Barata, permanecendo influente como nos escritos e projetos de Mario Pedrosa, mas também nos compêndios sobre arte brasileira de autores tão distintos quanto Rodrigo de Melo Franco (1952), José Teixeira Leite (1979), Pietro Maria Bardi (1981) e Walter Zanini (1983), ou sobrevivendo até o limiar do século XXI na Mostra 
do Redescobrimento, de 2000, e na mais recente publicação da editora Martins Fontes (2015), que abre os capítulos com um texto dedicado à arte indígena.

Qual seria a importância de debater essa operação discursiva e simbólica na atualidade, quando as preocupações de historiadores da arte, pesquisadores e curadores se voltam para necessidade de ampliação e revisão dos cânones das narrativas da arte produzidas no Brasil? Mais ainda, quando vozes indígenas, de artistas a curadores, pesquisadores a produtores, demandam uma reparação histórica, uma retomada dos espaços da história, do museu e do patrimônio aos quais lhes foi negada a entrada como sujeitos, ocupando-as como objetos de estudo, repertório, tema e inspiração, como se fossem uma natureza à disposição de artistas, pesquisadores e idealizadores de identidades supostamente constitutivas da "brasilidade"?

No contexto de Eduardo Prado, incluir a arte indígena em uma narrativa sobre a arte nacional significava um marco importante - como já analisaram Jens Andemann (2004) e Sven Schuster (2015) significava descobrir, ou inventar, para o Brasil uma Antiguidade equivalente àquela das grandes civilizações americanas, equiparando-as às civilizações europeias. Sem sombra de dúvida, a então recente descoberta dos hieróglifos marajoaras, da cerâmica dos povos amazônicos e dos zoólitos antropomórficos no norte e sul do Brasil, provava para os cientistas brasileiros da época que o Brasil havia tido uma antiga civilização e assim, portanto, podia reivindicar sua própria antiguidade, sua superioridade como civilização. O Brasil tinha seu próprio “kunstwollen", um pendor artístico que justificava sua inclusão no concerto das civilizações. Produzir a genealogia desse discurso das origens, de tão longa fortuna, é imprescindível para que, hoje, possamos fazer a análise crítica das implicações dessas narrativas, como já salientou Daniela Kern (2017).

Atualmente, no contexto dos estudos de história da arte no Brasil, em que se destacam os esforços de crítica dos cânones que estruturaram a disciplina, bem como a premência da necessidade de refletir sobre seus 
pressupostos coloniais, com raras exceções, ainda não se reavaliou o lugar construído para a arte indígena em suas narrativas, diferentemente com o que ocorre em contextos como os da Austrália, Canadá e, em menor escala, dos Estados Unidos, a despeito de toda riqueza e densidade de debate que vem ocorrendo nos campos da antropologia, etnologia e da museologia. A antropologia e a etnologia produziram os mais profundos e originais estudos a respeito das diversas manifestações artísticas dos povos indígenas vivendo em território brasileiro. Dos estudos pioneiros de Gastão Cruls (1952), aos de Berta Ribeiro (1957 e 1989, entre outros) Maria Heloisa Fénelon Costa $(1978,1983,1988)$ Els Lagrou (2007), Lux Vidal (1992), André Prous (2007), Dominique Gallois (2006), Artistóteles Barcelos Neto (2008), Pedro Cesarino (2013), entre tantos outros, constituiu-se um corpo de reflexão, em diálogo com comunidades, agentes e artistas indígenas que precisam ser mais conhecidos e debatidos entre os historiadores da arte.

É urgente responder à articulação sem precedentes, proveniente do campo indígena, para criar condições de visibilidade da cultura material e da produção artística de autores indígenas, individuais ou coletivos, nas instituições de arte no Brasil. Pois se momento atual assiste a um esforço de repensar o colecionismo e musealização da cultura material dos diferentes povos indígenas nos museus de arqueologia e etnografia, debatendo questões de representação, repatriamento e modelos curatoriais, as instituições artísticas, incluindo aí o campo da história da arte, necessitam participar desse movimento, apoiando e refletindo criticamente sobre a intensa e crescente participação de artistas indígenas nos circuitos de arte contemporânea, mas também considerando de maneira crítica as formas de contar e mostrar a história da arte indígena, que tem seus critérios, temporalidades e modos próprios ${ }^{30}$.

Como a disciplina da história da arte responde ao protagonismo de artistas e pesquisadores indígenas hoje? Como é capaz colaborar para a reparação de omissões, apropriações e desvalorizações do passado? Como é 
capaz, nesse processo, de reavaliar seus critérios, periodizações e métodos? Como pode contribuir para a reflexão sobre questões relativas à repatriação e autorias compartilhadas? Como pode enfrentar essas questões no campo das práticas museológicas, incidindo sobre mudanças necessárias de suas políticas de acervos e de exposições? Como pode promover uma discussão crítica dos movimentos do mercado e as pressões pela internacionalização? Como pode fomentar os estudos locais, mas em diálogo com os debates internacionais de modo a expandir as fronteiras da discussão, e fortalecer redes de troca acadêmica e de proteção às culturas indígenas? Sobretudo, como pode se deixar rever e repensar pelos próprios indígenas pesquisadores, artistas, anciãos, criadores -, e tornar-se aliada na circulação e valorização de seus saberes, na defesa de seus modos de vida, de seus patrimônios territoriais e imateriais, indissociáveis da cultura material e artística que produzem?

Naine Terena, curadora da mostra Véxoa: nós sabemos, realizada em 2020 na Pinacoteca de São Paulo, afirma a necessidade dessa reviravolta na história da arte no Brasil. Em seu texto curatorial, convida a repensar e recompor essa história, alterando perspectivas. Sugere incorporar, deslocando de seu âmbito etnográfico, obras como os desenhos de pessoas Guarani-Kaiowá, recolhidos pelo antropólogo Egon Schaden, na década de 1960, acerca da subida de um médico-feiticeiro ao céu. Ou ainda o desenho da mulher Yawalapiti, feito em 1911 e recolhido por Fritz Krause (18811963), no qual retrata o seu marido. Lembra ainda de Sibé (Feliciano) Lana, considerado um dos precursores da arte indígena contemporânea, já na década de 1960. Poderíamos ainda acrescentar, como nos lembra Denilson Baniwa, dos desenhos de Guido de Mello Rego, o menino Bororo ${ }^{31}$, das obras de Luiz Lana, primo-irmão de Feliciano, do Pajé Gabriel Gentil Tukano, ou ainda aqueles artistas do alto Rio Negro que cederam seus desenhos para Theodor Koch-Grünberg (1905), publicados em Começos da arte na selva ${ }^{32}$. Eles e tantos outros que desde a invasão europeia têm compartilhado seus 
saberes, seu olhar e sua arte com os não-indígenas.

O reconhecimento dessas produções gráficas feitas "a partir do olhar dos indivíduos que as traçaram" (Terena, 2020: 12), não só pela demanda daqueles que as solicitaram ou delas se apropriaram, é tardio, como pontua a autora, "porque essas vozes não foram ouvidas"(Ibidem). Se hoje, diante da "queda do céu" ${ }^{33}$, elas o são, cabe também pensar o lugar a ser ocupado pelas produções coletivas, relegadas ao anonimato, ao âmbito do artesanato ou das artes utilitárias, ou ainda em como a história da arte vai se relacionar com as formas imateriais que impregnam essas produções - códigos cerimoniais, memórias, encantamentos, visões e sonhos.

Atravessada por uma história de apagamentos, essa visibilidade hoje, demandada e agenciada por artistas e pesquisadores indígenas, coincide com o campo político e de resistência, pontuando um momento em que a arte indígena propõe "dialogar com as "gentes comuns" do Brasil e do mundo" (Ibidem). Essas demandas e agências resultam do próprio processo de autoorganização e autorrepresentação indígena, que afirma a autonomia de seus modos de vida e de seus territórios. A arte indígena hoje, como afirma Terena "é a tradutora de todas as falas, lutas, derrotas, vitórias, perspectivas e assume um diálogo amplo com a sociedade civil" (Ibidem: 13).

Se abro esse artigo com uma série de perguntas e o encerro com uma série de outras, é porque me sinto convocada a um encontro por demais adiado. Um encontro tenso, complexo e muitas vezes constrangedor, mas do qual é urgente não mais fugir. Há quem nos espera à mesa:

Quem eu sou?

Eu sou o medo dos brancos

Eu sou aquele que senta na mesa dos doutorados

Que desestabiliza e causa constrangimento a todos

Que ri do vocabulário prolixo e do currículo lattes dessa

gente branca 
Eu sou o novo cabano

Eu sou a resistência através da antropofagia

Eu sou aquele que degola Tarsila do Amaral

Eu sou aquele que empala Mário de Andrade

Eu sou aquele que come o coração de Oswald de Andrade

Eu sou a arte Indígena

Eu sou o Indígena contemporâneo. (Baniwa, 2018b, apud Diniz, 2020: 79)

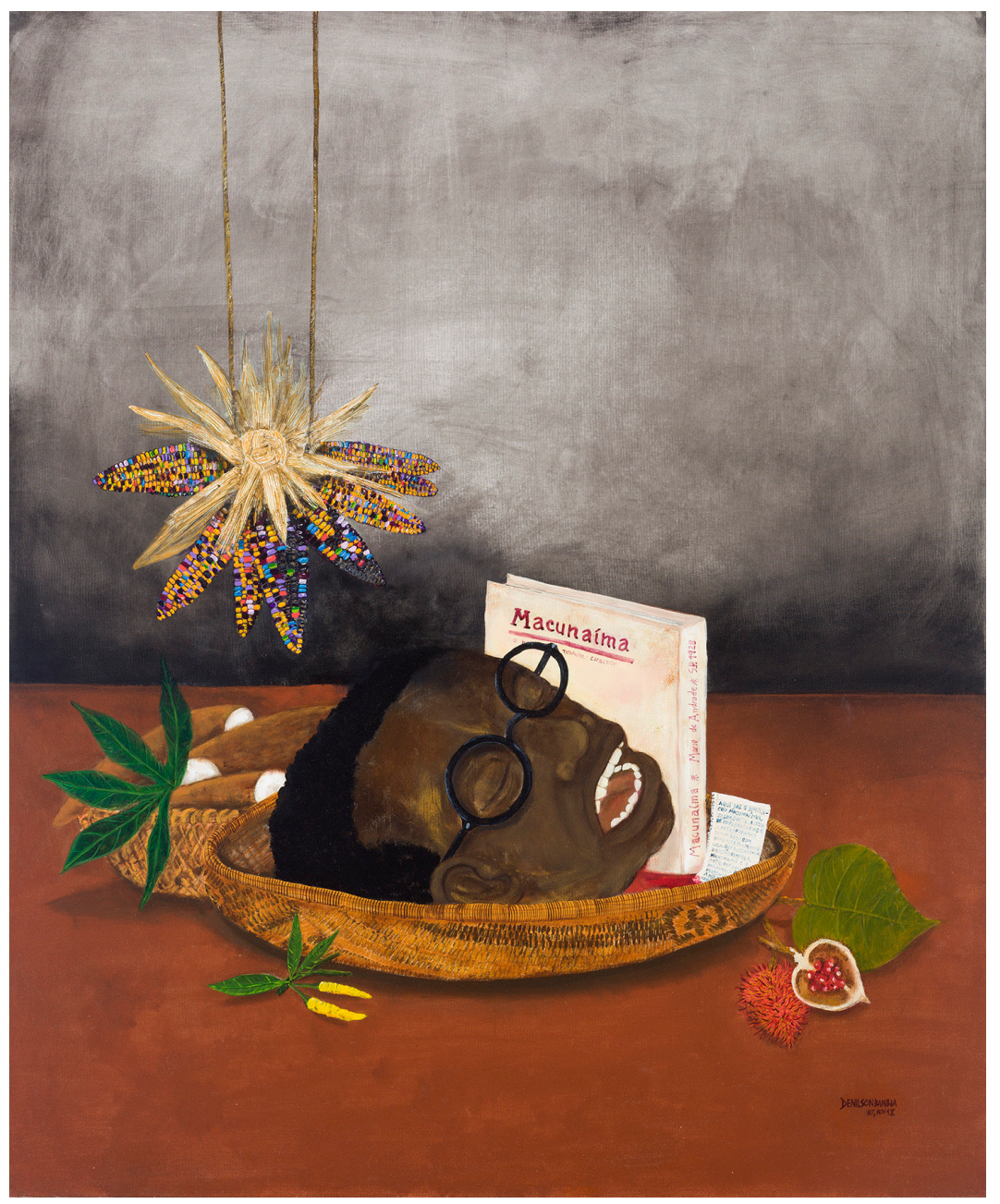

FIG. 8. Denilson Baniwa, Re-antropofagia, 2019, acrílica, argila, óleo, puçanga e urucum sobre tela, $120 \times 100 \mathrm{~cm}$. Coleção do artista, em comodato com a Pinacoteca de São Paulo. Crédito fotográfico Isabella Matheus / Pinacoteca de São Paulo. 


\section{Referências}

ANDERMANN, J. Espetáculos da diferença: A exposição antropológica brasileira de 1882. Topoi, n.9, vol.5, p.128-170, jul./-dez. 2004.

ANDRADE, R. M. F. As Artes Plásticas no Brasil, v.1. Rio de Janeiro: Lagaroti, 1952. . Arte Indayá. Diário Nacional, São Paulo, 21 jan.1928. . Escola Hadleriana. Diário Nacional, São Paulo, 22 jan.1932. . Aspectos das artes plásticas no Brasil. São Paulo: Livraria Martins, 1965.

BANIWA, D. Performance Pajé-Onça hackeando a $33^{\text {a }}$ Bienal de Artes de São Paulo. São Paulo, 17 de novembro de 2018. Disponível em: https://www.youtube.com/ watch?v=MGFU7aG8kgI. Transcrição de Clarissa Diniz. In: DINIZ, Clarissa. Street fight, vingança e guerra: artistas indígenas para além do 'produzir ou morrer'. Espaço Ameríndio, Porto Alegre, v. 14, n. 1, pp. 68-88, jan./jul. 2020.

. Quem sou eu? Transcrição de Clarissa Diniz. In: DINIZ, C. Street fight, vingança e guerra: artistas indígenas para além do "produzir ou morrer". Espaço Ameríndio, Porto Alegre, v. 14, n. 1, pp. 68-88, jan./jul. 2020.

BARBUY, H. A exposição universal de 1889 em Paris: visão e representação na sociedade industrial. São Paulo: Edições Loyola, 1999.

BARCELOS NETO, A. Apapaatai: Rituais de máscaras no Alto Xingu. São Paulo: EDUSP, 2008.

BARCINSKI, F.W. (org.). Sobre a arte brasileira: da pré-história aos anos 1960. São Paulo: Livraria e Editora Martins Fontes, 2015.

BARDI, P. Maria. História da Arte Brasileira. São Paulo: Melhoramentos, 1981.

BATISTA, G. N. O que dizer sobre a política africana no Brasil e as artes? Reflexões sobre a Coleção Africana do Museu Nacional de Belas Artes (1961-1964). Dissertação (Mestrado em Artes Visuais) - ENBA, Universidade Federal do Rio de Janeiro, 2018.

BERLO, J C. The Early years of Native American art history: the politics of scholarship and collecting. Seattle: University of Washington Press, 1992.

BOUVIER, B. Charles Garnier (1825-1898) architecte historien de L'Habitation humaine. Livraisons d'histoire de l'architecture, n.9, pp. 43-51, 1er semestre, 2005.

BRAGA, T. A planta brazileira (copiada do natural) e applicada à ornamentação. 1905-1914. Manuscrito.

BUONO, A. Seu tesouro são penas de pássaro: arte plumária tupinambá e a imagem da América. Figura. Studies on the Classical Tradition,Campinas, v.6, n.2, pp.13-29, 2019.

EXPOSITION UNIVERSELLE DE 1889. Catalogue Général Officiel. Lille: Impr. L. Danei, $8 \mathrm{v} ., 1889$. 
CESARINO, P. Cartografias do cosmos: conhecimento, iconografia e artes verbais entre os Marubo. Mana, Rio de Janeiro, v. 19, n. 3, pp.437-471, 2013.

COSTA, A. Introdução à arqueologia brasileira: etnografia e história. São Paulo: Companhia Editora Nacional, 1938.

COSTA, M. H. F. A Arte e O Artista Na Sociedade Karajá. Brasília: FUNAI-Departamento geral de Planejamento comunitário-Divisão de Estudos e Pesquisas, 1978.

Museu Nacional de Belas Artes. Arte indígena brasileira. Rio de Janeiro: Museu Nacional de Belas Artes, 1983.

O Mundo dos Mehináku e Suas Representações Visuais. Brasília-Distrito Federal: Editora UnB, 1988.

CRULS, G. Arte indígena. In: ANDRADE, Rodrigo M.F. (org.). As Artes Plásticas no Brasil. Rio de Janeiro: Ed. Instituto Lagarrotini. 1952.

DAVIS, E.B.; CARR, D.; GADSDEN, N., et. al. (orgs). A New World Imagined: Art of the Americas. 1 ed. Boston, Nova York: MFA Publications: D.A.P., 2010.

DENIS, R. C.; TRODD, C. Art and the academy in the nineteenth century. Manchester: Manchester University Press, 2000.

DINIZ, C. Street fight, vingança e guerra: artistas indígenas para além do 'produzir ou morrer'. Espaço Ameríndio, Porto Alegre, v. 14, n. 1, pp. 68-88, jan./jul., 2020.

DUMAS, F. G., FOUCARD, G. (orgs.). Revue de l'Exposition universelle de 1889. Paris: Motteroz/Baschet, 1889.

EMPIRE DU BRÉSIL.Catalogue Officiel. Paris: Imp. de Chaix, 1889.

ERRINGTON, S. What became authentic primitive art? Cultural Anthropology. v.9, n.2, pp.201-226, maio 1994.

ESTRADA, G. D. A Arte Brasileira. Introdução e notas Tadeu Chiarelli. Col. Arte: Ensaios e Documentos. Campinas: Mercado das Letras, 1995.

FERREIRA, F. ““As artes industriais indígenas”, Revista da Exposição Anthropológica Brazileira, Rio de Janeiro: Typographia de Pinheiro e C., 1882. pp. 107-108.

FERREIRA, F. Belas Artes, estudos e apreciações. Introdução e notas Tadeu Chiarelli. Porto Alegre: Zouk, 2012.

GALLOIS, D. T. Wajãpi: Expressão gráfica e oralidade entre os Wajãpi do Amapá. Brasília, DF: Instituto do Patrimônio Histórico e Artístico Nacional, 2006.

GARRIGAN, S. E. Collecting Mexico: museums, monuments, and the creation of national identity. Minneapolis: University of Minnesota Press, 2012.

GOLDSTEIN, I. S. Da "representação das sobras" à "reantropofagia": Povos indígenas e arte contemporânea no Brasil. MODOS, v. 3, n. 3, pp. 68-96, set./dez. 2019.

GOLDSTEIN, I. Arte indígena como conexão”. In: TERENA, N. (org.). Véxoa: Nós sabemos. 1ed. São Paulo: Pinacoteca do Estado de São Paulo, 2020.

GODOY, P. B. Carlos Hadler: apóstolo de uma arte nacionalista. Tese (Doutorado em 
História) - IFCH, Universidade Estadual de Campinas. Campinas, 2004.

HARTT, C. F. Beginning of art, or evolution in ornament. Proceedings of the University convocation, held at Albany. Albany, NY: University of the State of New York, pp. 143-152, 1873 .

HARTT, C. F. "A origem da arte ou evolução da ornamentação", Revista da Exposição Anthropológica Brazileira, Rio de Janeiro: Typographia de Pinheiro e C., 1882. pp.42-50.

HAZAN, H. Essential others: anthropology and the return of the old savage. International Journal of Sociology and Social Policy, v.29, n.1-2, pp.60-72, 2009.

HUTCHINSON, E. The Indian craze primitivism, modernism, and transculturation in American art, 1890-1915. Durham [NC]: Duke University Press, 2009.

JIMÉNEZ, M. A 'Primitive' Latin America on View at the 1889 Exposition Universelle. Journal of Curatorial Studies, v.3, n. 2-3, pp.194-211, jun. 2014.

KARP, I.; LAVINE, S. Exhibiting cultures: the poetics and politics of museum display. Washington: Smithsonian Institution Press, 1991.

KERN, D. Entre Darwin e Ruskin: Charles Frederick Hartt e a evolução no ornamento. In: ENCONTRO DE HISTÓRIA DA ARTE, 6., Campinas, 2010. Anais... Campinas: UNICAMP/IFCH, 2010, pp. 120-126.

Tirando o Pó das Brazilian Antiquities: Charles Frederick Hartt relido por Anna Roosevelt. Revista de História da Arte e Arqueologia, Campinas, v. 1, pp. 39-55, 2011. A reopened formal sequence: The Brazilian case of Neomarajoara motives. In: INTERNATIONAL CONGRESS OF AMERICANISTS, 54., Viena, 2012. Resúmenes/ Abstracts... Viena: Universidade de Viena, 2012, pp. 317-317.

'Por que não flores?' Charles Frederick Hartt e a busca pela beleza ruskiniana na cerâmica marajoara. In: ENCONTRO DA ASSOCIAÇÃO NACIONAL DE PESQUISADORES EM ARTES PLÁSTICAS, 22., Belém, 2013. Belém: ANPAP, 2013, pp. 330-341.

"The Amazonian Idol': The Naissance of a National Symbol in the Empire of Brazil (1848-1885). In: BIAGINI, Antonello F.; MOTTA, (orgs.). Empires and Nations from the Eighteenth to the Twentieth Century. Newcastle upon Tyne, UK: Cambridge Scholars Publishing, 2014, pp. 214-221.

Historiography of Indian Art in Brazil and the Native Voice as Missing Perspective. In: AVOLESE, C. M.; CONDURU, R. (orgs.). New Worlds: Frontiers, Inclusion, Utopias. São Paulo: Comitê Brasileiro de História da Arte (CBHA); Comité International de l'Histoire de l'Art e Vasto, 2017, pp.101-115.

KOCH-GRUNBERG, T. Anfänge der Kunst im Urwald: Indianer-Handzeichnungen auf seinen Reisen in Brasilien gesammelt. Berlin: E. Wasmuth a.-g, 1905.

KOCH-GRUNBERG, T. Começos da arte na selva: Desenhos manuais de indígenas colecionados por Dr. Theodor Koch-Grünberg em suas viagens pelo Brasil. Manaus: Editora da Universidade Federal do Amazonas, 1990.

KOPENAWA, D.; ALBERT, B. A queda do céu: palavras de um xamã yanomami. São Paulo: 
Companhia das Letras, 2016.

LAGROU, E. M. A fluidez da forma: Arte, alteridade e agência em uma sociedade amazônica (Kaxinawa, Acre). Rio de Janeiro: Topbooks, 2007.

LEITE, J. R. T. Arte no Brasil. Rio de Janeiro: Editora Abril, 1979.

LENÔTRE, G. Courier de L'Exposition, Le Monde Illustrée. n.1684, Paris, 6 de julho de 1889, pp.3-4.

LERY, J. de. Viagem à terra do Brasil. Rio de Janeiro: Biblioteca do Exército Editora 1961.

LÉVASSEUR, E. (dir). Le Brésil. 2.ed. Paris: H. Lamirault et Cie/Syndicat FrancoBrésilien, 1889.

MONOD, E. L'Exposition universelle de 1889: grand ouvrage illustré, historique, encyclopédique, descriptif. Paris: E. Dentu. 4V., 1890.

MONTEIRO, V e DUCHARTRE, P.-L. Légendes, Croyances et Talismans des Indiens de l'Amazonie. Paris: Tolmer, 1923.

MUSEU NACIONAL. Archivos do Museu Nacional. Rio de Janeiro: Typographia e Lith. Economica, 1885, vol.6.

MUSEU NACIONAL DE BELAS ARTES/ IBRAM / MINC. Plano Museológico 2016-2020. Rio de Janeiro, MNBA/Ibram/Minc, 2019.

NETO, J. A. S. Na seara das cousas indígenas: cerâmica marajoara, arte nacional e representação pictórica do índio no trânsito Belém e Rio de Janeiro (1871-1929). Dissertação (Mestrado em História Social da Amazônia) - Instituto de Filosofia e Ciências Humanas, Universidade Federal do Pará. Belém, 2014.

NETTO, L. Le Musée national de Rio-de-janeiro et son influence sur les sciences naturelles au Brésil. Paris: Ch. Delagrave, 1889.

PASTANA, M. Cerâmica pré-histórica de Marajó. O Careta, Rio de Janeiro: n. 1, p. 519, 1937.

PEDROSA, M. Museu das Origens, projeto para a reconstrução do MAM Rio, 1978. (Dactiloscrito).

PEÑAFIEL, A. Explication de l'édifice Mexicain à l'exposition internationale de Paris, en 1889. Barcelona: Impr., 1889.

PEÑAFIEL, A. Monumentos del arte mexicano antiguo. ornamentación, mitología, tributos y monumentos. Berlim: A. Asher \& Co., 1890.

PICARD, Alfred (dir.). Exposition universelle internationale, rapport général. Paris: Imprimerie Nationale, 1891.

PONTUAL, R. Tradição e ruptura: síntese de arte e cultura brasileiras. São Paulo: Fundação Bienal de São Paulo, 1985.

PROUS, A.; PIMENTEL, L. G. Arte pré-histórica no Brasil. Belo Horizonte: Editora C/Arte, 2007.

REGO, M. C. Guido (páginas de dor). Rio de Janeiro: Typographia Leuzinger, 1895.

RIBEIRO, D.; RIBEIRO, B. G. Arte plumária dos índios kaapor. Rio de Janeiro: Laboratórios 
Silva-Araujo Roussel, 1957.

RIBEIRO, B. Arte indígena, linguagem visual: Indigenous art, visual language. Belo Horizonte: Editora Itatiaia Limitada, 1989.

SCHAAN, D. P. A linguagem iconográfica da cerâmica Marajoara. Porto Alegre: Edipucrs, 1997.

SCHUSTER, S. The 'Brazilian Native' on Display: Indianist Artwork and Ethnographic Exhibits at the World's Fairs, 1862-1889. RIHA Journal, 2015. https://doi.org/10.11588/ riha.2015.0.70090.

SQUEFF, L. C. Uma galeria para o Império: a Coleção Escola Brasileira e as origens do Museu Nacional de Belas Artes. São Paulo: Edusp, 2012.

TENORIO-TRILLO, M. Mexico at the World's Fairs, Crafting a Modern Nation. Berkeley, Los Angeles, Oxford: University of California Press, 1996.

TERENA, N. (org.). Véxoa: Nós sabemos. 1ed. São Paulo: Pinacoteca do Estado de São Paulo, 2020.

TREECE, D. Exilados, Aliados, Rebeldes, o movimento indianista, a política indigenista e o Estado-Nação Imperial. São Paulo: Edusp, 2008.

VALIANT, S. Ornamental Nationalism. Archaeology and Antiquities in Mexico, 1876-1911. Leiden: Brill, 2018.

VEL ZOLAD, R. W. O Impressionismo de Guido, um Menino Índio Bororó. Rio de Janeiro: Ed. Universitária Santa Úrsula, 1990.

VIANA, M. L. Arte Decorativa na Escola Nacional de Belas Artes - Inserção, conquista de espaço e ocupação (1930-1950). Tese (Doutorado em Artes Visuais - História e Crítica da Arte) - Escola de Belas Artes Universidade Federal do Rio de Janeiro. Rio de Janeiro, 2015 .

VIDAL, L. B. Grafismo indígena: estudos de antropologia estética. São Paulo: Studio Nobel/ Usp/Fapesp, 1992.

WALTON, W. Chefs-d'oeuvre de l'Exposition Universelle de Paris, 1889. Philadelphia: G. Barrie, 1889.

ZANINI, Walter (org.). História geral da arte no Brasil. São Paulo: Instituto Walther Moreira Salles, 1983.

\section{Notas}

* Fernanda Pitta, curadora da Pinacoteca de São Paulo e professora da pós-graduação em História da Arte na FAAP-SP. E-mail: fpitta@pinacoteca.org.br. ORCID: https://orcid.org/0000-0002-9892-5380. 
1 "La reconstitution en est consciencieuse et savante ; les documents les plus rares et les plus sérieux [...] un petit musée des antiquités américaines, [...]. Il est curieux, ce minuscule musée : il y a là des costumes complets de Botocudos et de Chivaros qui ne tiennent pas grand' place, car ils i consistent seulement en massues et en boucles d'oreilles; il y a des vases préhistoriques chargés d'hiéroglyphes mystérieux et presque artistiques; on y voit aussi, dans un bocal, une horrible tête d'homme désossée et cuite au four qui n'a d'ailleurs rien de préhistorique, puisque cette atroce cuisine ne date que de deux ans à peine; on y peut aussi étudier tous les vestiges d'une religion primitive, sur lesquels nous glisserons discrètement; ceux de nos lecteurs qui ont visité le musée secret de Naples et les antiquités pompéiennes comprendront la raison de notre réserve."

2 "Pour le paysage européen, les écoles sont créées, les modèles connus. Devant une nature dont la reproduction ne se retrouve pas dans les toiles des maîtres l'individualité de l'artiste doit se révéler dans la façon de rendre cette nature dont les violences de ton et les formes exotiques risquent d’impressionner désagréablement l'œil exercé d'un connaisseur européen". Salvo contrário, todas as traduções são da autora.

3 "Depuis Post et Van Eckhout les paysagens du Brésil n’ont encore trouvé leur grand peintre."

4 "Um beau tableau."

5 "Un élève remarquable de Cabanel."

6 "Les grandes qualités de l’artiste."

7 "Préocupation artistique."

8 "Ont une grande valeur parce qu'elles démontrent que la préoccupation artistique devient plus générale."

9"Une certaine classe de individus."

10 "Qu'une grande partie de la population sache un peu le dessin que d'avoir trois ou quatre Meissoniers ou Cabanels."

11 "L’art rudimentaire qu'on rencontrait chez les indiens du Brésil."

12 "Un certain développement marqué dans la beauté des formes."

13 "Ou peut-être le passage sur les bords du grand fleuve, de tribus plus avancées, au moins sous le rapport industriel, que leurs successeurs actuels dans les mêmes régions."

14 " Et savent faire les plus belles oppositions et gradations de couleurs, avec le rouge couleur de feu éclatant, le jaune d'une riche teinte jonquille et le bleu le plus beau."

15 Daniela Kern analisou as ideias de Hartt em relação a Ruskin. veja em Kern (2010; 2013).

16 " Du jour où l’œuvre du potier, dit-il, a été conçue comme un symbole, du jour où le vase a été imaginé, non plus pour un usage domestique, mais pour exprimer une pensée ou un sentiment, pour devenir un présent d'amitié, un gage d'amour ou un pur objet de luxe, la céramique s'cst élevée au rang des arts et c'est alors qu'elle a dû se soumettre aux trois conditions éternelles du beau: l'ordre, la proportion et l'harmonie."

17 "Qui est en même temps la plus haute et la première expression de l'art."

18 "Ils révèlent tous une préoccupation de beauté de la part de l'artiste qui ne s'est plus contenté d'obtenir la simple convenance, au tant quant aux formes qu'à la décoration gravée et peinte."

19 "La première condition des produits céramiques, c'est à-dire un sens bien accusé, ou si l'on veut, une 
dimension dominante. Pour donner une idée de leur caractère et de leur originalité, il suffit de dire que malgré la beauté de ces vases, on ne peut à la rigueur les identifier entièrement dans leur forme avec aucun vase grec, car ils présentent des combinaisons vraiment nouvelles de l'ovoïde avec les formes cylindriques et clavoides agrémentées de renflements e de rétrécissements harmonieux. Quant à leur polychromie, ell est caractérisée par le jaune, le gris, le rose, le rouge orangé et un peu de noir dans les détails, mais jamais comme fond. Ce qui semble le plus curieux dans l'ornementation de ces vases, c'est qu'on y voit trois ornementations assez distinctes les unes des autres : les grecques soit rectilignes soit curvilignes à enroulements ondés et contenus ; les ornements à lignes brisées, reliées en spirale; dans deux vases gris ornés de noir on ne retrouve aucun de ces caractères. Les objets sculptés doivent être antérieurs aux poteries peintes. Les études faites jusqu'à ce jour n'autorisent aucune tentative de classement. Les découvertes de Marajó sont récentes, et le problème du passage par L'Amazone, d'hommes plus civilisés que les Indiens actuels appartenant aux hypothèses des ethnographes sort de notre plan; nous avons voulu à peine signaler ces découvertes de Marajó, que le Muséum de Rio-de-Janeiro a fait connaître dans le savant recueil de ses Archivos déjà cité et dont la publication est dûe à M. Ladislau Netto."

20 Denilson Baniwa. Hackeando a 33ª bienal. Performance, 2018 (apud Diniz, 2020: 79).

21 Durante os anos 1990, na Antropologia da Arte do PPGAV-UFRJ houve um esforço de situar a pesquisa dessa produção dentro do campo da história da arte, encabeçado pelas antropólogas Berta Ribeiro e Maria Heloisa Fénelon Costa, figuras centrais da pesquisa antropológica da arte indígena. Ambas orientaram pesquisas que promoveram um diálogo da disciplina com essa produção.

22 Veja por exemplo: Goldstein (2020; 2019), e Kern (2010; 2011; 2013; 2014 e 2017). Ambas as pesquisas são fundamentais para as reflexões apresentadas neste artigo.

23 A coleção de arte indígena do MNBA atualmente, segundo o plano museológico do Museu, de 2019, é composta de 51 itens (MNBA/Ibram/ Minc, 2019: 11).

24 Segundo a pesquisa de Gabrielle Nascimento Batista, Teixeira Leite cria uma coleção de arte indígena com 28 itens para o MNBA, quando também organiza a coleção de arte africana do museu, cf.: (Batista, 2018: 130)

25 A Pinacoteca adquire obras de Jaider Esbell, Feitiço para salvar a Raposa Terra do Sol, 2019, e Denilson Baniwa, Enfim, 'civilização', O antropólogo moderno já nasceu antigo, Vitrine, Luto e Voyeurs, todas de 2019, propostas pelo corpo curatorial do museu, através do Programa de Patronos de Arte Contemporânea da Pinacoteca, em 2019. A única obra de artista indígena presente no acervo até aquele momento era uma Ritxòkò Iny (boneca karajá), percentence ao comodato Nemirovsky.

$26 \mathrm{Na}$ bienal de 1975, a sala especial Xingu-Terra contou com a presença do cacique Aritana Yawalapiti, então com 24 anos, como artista convidado, que construiu uma maloca com objetos do cotidiano laualapitis. A iniciativa, coordenada por Orlando e Claudio Villas Bôas, contou também com trabalhos visuais e sonoros de Maureen Bisiliat, Eduardo Magalhães, Dulce Soares, André Terner, Jacuqes Brayton, Claudio Kubrusly e Marcelo Tassara, Gisela Magalhães e Fernando Lion foram os arquitetos responsáveis. Ver http://www.bienal.org.br/post/557.

27 Para uma discussão da proposta de Pedrosa, também em relação à atuação de Teixeira Leite no MNBA (Batista, 2018).

28 Para um estudo de Carlos Hadler e o manuscrito Marajoara: 88 motivos ornamentais, veja Godoy (2004). 
29 Para o estudo do neomarajoara na Escola Nacional de Belas Artes, veja Viana (2015).

30 Essas problemáticas foram abordadas por Naine Terena na curadoria da mostra Véxoa: nós sabemos, com a qual pude colaborar, e no seu ensaio para o catálogo da exibição (Terena, 2020). Agradeço a Naine a confiança e a troca de reflexões e questionamentos que verdadeiramente informam minha abordagem da questão, bem como aos ensinamentos de Denilson Baniwa e Jamille Pinheiro Dias, companheiros fundamentais desses debates. Algumas dessas conversas também foram contempladas na série de debates on-line organizadas por Naine Terena, Jamille Pinheiro Dias e por mim, realizada, entre 2020 e 2021, pela Pinacoteca de São Paulo e o projeto CARLA - Cultures of Anti-Racism in Latin America, da Universidade de Manchester, em torno da exposição: "Futuros da Arte Indígena" (https://www.youtube.com/watch?v=b8fPmQLna2E\&t=692s); "Curando com a arte indígena" (https://www.youtube.com/watch?v=kx6V19GR2EY\&t=3643s); "Mulheres artistas indígenas: questões de gênero na produção e reconhecimento" (https://www.youtube.com/ watch?v=MtuFcD2L9JE\&t=2s); "As artes indígenas e as culturas de resistência" (https://www. youtube.com/watch?v=ml7FMPXWwCo\&t=9s). Também sobre Véxoa, veja o filme dirigido por Jamille Pinheiro Dias e Debora McDowell, Terra fértil: Véxoa e arte indígena contemporânea na Pinacoteca de São Paulo (https://www.youtube.com/watch?v=0zztkhAsMc4).

31 Sobre Guido, veja Rego (1895) e Vel Zoladz (1990).

32 Anfänge der Kunst im Urwald: Indianer-Handzeichnungen aufseinen Reisen in Brasilien gesammelt. Berlin: E. Wasmuth a.-g, 1905., publicado no Brasil como Começos da arte na selva: Desenhos manuais de indígenas colecionados por Dr. Theodor Koch-Grünberg em suas viagens pelo Brasil. Manaus: Editora da Universidade Federal do Amazonas, 1990.

33 A expressão é de Davi Kopenawa Yanomami (Kopenawa; Albert, 2016)

Artigo enviado em junho de 2021. Aceito em agosto de 2021. 